AperTO - Archivio Istituzionale Open Access dell'Università di Torino

\title{
Stakeholder Definition in a Network Context: The Case of Piazza dei Mestieri
}

\section{This is the author's manuscript}

Original Citation:

\section{Availability:}

This version is available http://hdl.handle.net/2318/1654907

Publisher:

Springer

Published version:

DOI:10.1007/978-3-319-62785-4_3

Terms of use:

Open Access

Anyone can freely access the full text of works made available as "Open Access". Works made available under a Creative Commons license can be used according to the terms and conditions of said license. Use of all other works requires consent of the right holder (author or publisher) if not exempted from copyright protection by the applicable law. 


\section{Stakeholder Definition in a Network Context: The Case of Piazza dei Mestieri}

Laura Corazza $1 \square$

Email laura.corazza@unito.it AQ1

Maurizio Cisi 1

Emailmaurizio.cisi@unito.it

1 Department of Management, University of Turin, Corso Unione Sovietica 218 bis, 10134 Turin, Italy

\section{Abstract}

This article contributes to the body of stakeholder literature by providing a detailed analysis of the dynamics that pragmatically occur in a firm during the process of analysis of stakeholder relationships. This process can be fragmented when an entity operates through a coordinated combination of different firms (with several legal entities) that form a network. The application of stakeholder thinking could be difficult when the overall purpose of the network is to provide social goods for increasing social welfare in a critical community. Recent trends in the stakeholder salience model, such as stakeholder relationships model will be analyzed in detail. The case study focuses on a network of several entities that provide training and work possibilities to early school dropouts, i.e. young disadvantage people. The network analyzed is located in Italy and it is composed by several legal entities like profit, not-for-profit and training agencies. In recent years, the business model adopted by the network has demonstrated its validity in contrasting the social phenomena, and the network is currently in expansion. The methodological approach used is a Participatory Active Research (PAR) one, particularly important for testing the efficient application of a theory or the evolution of a theory in a proper manner. The case can add a contribution in the constant and still modern debate on stakeholder management in practice. Our research can bring useful insights for policy makers and all those organizations that provide guidelines for stakeholder engagement.

\section{Keywords}

\section{Stakeholders relationships \\ Stakeholders salience \\ Business network \\ Social enterprise}

The authors would like to thank all the people involved in the project and especially the board and top managers of Piazza dei Mestieri. In particular, we thank Giulia Mancini and Andrea Martra for their passionate work that helped us in collecting data and design the project. In addition, we thank Dario Odifreddi, Cristiana Poggio and Giovanni Clot for demonstrating further that the cooperation can generate positive and unexpected results. In particular, we are glad and honored to have met and joined their incredible environment that have taught us more than we ever imagined.

The process of determining stakeholders' salience may be complicated. In recent years, the term "stakeholder" has been widely used in literature and, conversely, it has been sometimes abused, in the real economy. The greater part of the business world currently agrees upon the importance of satisfying stakeholders' expectations through the business activities. The process of prioritization of these expectations could be more fragmented when an entity operates through a coordinated combination of different firms (with several legal entities) that do not compose a group (like a multinational corporation with numerous branches and subsidiaries), but rather act as a network of entities. Consequently, acting through a network allows a single company to go beyond its boundaries with ensuing significant changes in its value creation and operational practices as well as in its resulting governance. In a network of entities, each organization 
has its own relations with the external and internal environment and the management of these relations can overlap, be hostile or, become cooperative.

When a business creates value, for itself, its shareholder and its network of customers, suppliers, and complements, then, this business has acquired a strong competitive advantage (Freeman et al. 2004; Minoja et al. 2010; Minoja 2012). Also in this case, the process of stakeholder engagement should imply several realistic issues depending by the nature of the organizations (Boesso and Kumar 2009). If the nature of the business is related to the provision of social goods for increasing social welfare, some critical aspects related to the socio-economic and cultural contexts should also be taken into account. The linkage between stakeholder management and value creation process needs more efforts and, the existing approaches of stakeholder salience are not always effective in their pragmatic implementation (Kujala et al. 2012). AQ2

This article contributes to the body of stakeholder literature by providing a detailed analysis of the dynamics that pragmatically occur in a network of entities during the process of stakeholder management and engagement. The analysis of stakeholders in a network of entities is dynamic as well. A single entity can have an inner and outer stakeholder management perspective, and at the same time a network point of view. The process of prioritizing the stakeholders' expectations and relations is critical when, in a network, the entities move from a single entity point of view, to a network-as-a-whole perspective. In that case, the stakeholder salience model is not even effective, while a stakeholder relationships model would give a better narrative of the entire situation. In addition, the dynamics affecting the case study herein presented is amplified by the critic socio-economic features of the context.

The paper focuses on the case study of Piazza dei Mestieri: a network of Italian social enterprises that operates in the field of early school dropouts. The purpose of the study is to examine and narrate the complex activity of stakeholder recognition, prioritization, narrative and management within a network of social enterprises. The study is presented under the lens of the Economia Aziendale framework, the traditional Italian managerial theory which reinterprets in a more humanistic way the role of business organizations in society (Costa and Ramus 2012). In this approach, firms have an open nature and connectedness with their socio-economical surroundings and the purpose of their businesses is not only aimed at wealth creation, but also at the advancement of human social conditions (-Argandoña and von Weltzien Hø o Please check the $\varnothing$ ivik 2009; Signori and Rusconi 2009; Costa and Ramus 2012). The methodology applied for describing this case is derived from an interpretative research model called Participatory Action Research (PAR), where researchers take active part in the development of a project. This methodology is effective when there is a need for testing a theory and for explaining if, and how, business practices can use such a theory to bring successful insights to their operational practices.

The paper highlights the importance of the stakeholder relationships model when the value creation process is obtained through a network of entities (i.e. when the cooperation in the network is more effective than singular entities). Our contribution stresses the importance of orienting the overall network to achieve the mission and to uniformly share the vision as these elements strictly influence and are influenced by stakeholder relations. Finally, our work underlines the importance of a stakeholder relationships model to analyze the influences of various stakeholders in the value creation processes.

\section{Stakeholder Relationships in a Dynamic Context}

Managers can face several issues in dealing with the concept of stakeholders, starting from their recognition, to setting up fruitful relations. According to the stakeholder thinking, the company's development and survival in the long run are subjected to the ability of taking care of the network of relationships occurring among stakeholders (Freeman 1984; Freeman and Reed 1983). This managerial task deals with the ability of "influence, manage, or balance the set of relationships that can affect the achievement of an organization's purpose" (Freeman and Phillips 2002: 334). Managing and balance a diverse range of multiple stakeholder interests may be problematic because potential conflicting situation may arise (Freeman et al. 2007a). Signori and Rusconi (Signori and Rusconi 2009) outlined a clear model of essential pillars of Stakeholder Management Theory, intended as "genre of theories" (Freeman and Reed 1983; Freeman 1984; Evan and Edward Freeman 1993; Freeman 1994; Clarkson 1995; Donaldson and Preston 1995; Freeman and McVea 2001; Goodpaster 1991; Mitchell et al. 1997; Phillips 2003; Phillips et al. 2003; Buchholz and Rosenthal 
2005;Wicks and Edward Freeman 1998; Freeman et al. 2006; Freeman et al. 2010; Freeman et al. 2012; Freeman and Moutchnik 2013).

The rationalization of Stakeholder Management Theory (SMT) in pillars has been illustrated by the work of Signori and Rusconi (2009). The first pillar (SMT1) is the definition of stakeholder as 'any group or individual who is affected by or can affect the achievement of an organization's objectives' citing the work of Freeman and Mc Vea (2001: 189). The second pillar (SMT2) is the systemic view of the company as network of relationships; while, the third (SMT3) reflects the inner changes of an organization management that should take into account the complex of stakeholders needs and not only the traditional shareholders' perspective in developing managerial strategies and business conducts. The fourth pillar introduces the notion that the shareholders' interests are safeguarded and optimized by the maximization of the wellbeing of every stakeholder (SMT4). According to Signori and Rusconi's model (2009), SMT5 states that every business operation implies ethical aspects, clarifying that SMT is neither a socio-economic or political theory nor a comprehensive ethical theory (SMT6).

When a firm or an organization decides to conduct a stakeholder analysis, in order to determine those subjects that may wish to engage, it has to: (1) view the firm as a distinct entity that has a goal and purpose (Buscholz Buchholz and Rosenthal 2005); (2) locate the firm in a network of relationships (Rowley 1997); (3) clearly understand the dynamic of value creation in the community (Lozano 2005). Stakeholder identification is based on the recognition of stakes in a company, where a stake is a combination of interests, values, expectations and claims. As such, the management of relations between organizations and stakeholders implies a sort of prioritization (stakeholder salience) framed in a real (in most cases dynamic) perspective.

Stakeholder salience can be defined as the degree to which managers prioritize the competing claims of stakeholders' groups. In that sense, the perception of the claim is strictly connected to several attributes such as power, legitimacy and perceived urgency (Mitchell et al. 1997). The concept of power is derived from the ability of a stakeholder group to control those resources required by the firm (Pfeffer 1981). Hence, the more critical the resource controlled by a stakeholder group, the greater the significance the firm will attribute to that group. The more appropriate stakeholders' claims appear to be, the more attention managers will give to them. Appropriateness means legitimation and as such, the claims will be considered "desirable, proper or appropriate within some socially constructed systems of norms, values and beliefs" (Suchman 1995: 574). Finally, urgency involves time sensitiveness of manager in prioritizing specific claims. Urgency can be seen as the extent to which a stakeholder group is relatively active in claiming specific important issues. In addition, the multiple combination of these attributes creates greater salience than the individual presence of each of them. Crane and Ruebottom (2011) claim that there is a need to move away from a simplified standard of role-based identification of stakeholders toward a personalization of identities and interests. Previously, (McVea and Edward Freeman 2005) argued for a "names-and-faces approach", but the Social Identity model provides a deep understanding of social and economic identities altogether. This model tells more about how identities are formed, claims articulated, values expressed and action manifested (Crane and Ruebottom 2011). The Social Identity is a socially constructed definition of categories where members have unique characteristics mutually recognized and different from nonmembers. According to Crane and Ruebottom, Social identity theory stresses the category-based identities to which people feel attached and it should provide a robust identification of the relevant stakeholder groups, underlying motivations that are currently sidelined in stakeholder theory and providing a mechanism for proactive identification (Crane and Ruebottom 2011).

Furthermore, Garriga Cots (2011) adopts a so-called stakeholder social capital model based on four dimensions (structural, relational, cognitive and evaluative). In this approach, the new concept is "the goodwill that arises from a pattern of social relations (multiple and dense) between the firm and its stakeholders realized through members' meta-purpose and shared trust that contributed to the common good of both the stakeholder network and society" (Garriga Cots 2011: 337). Pragmatically, only a few works directly bring new insight applicable by firms. Among these works, Boesso and Kumar (2009), Myllykangas et al. (2010) and Kujala et al. (2012) have produced a discussion of stakeholder salience.

Recently, Boesso and Kumar (2009) have put emphasis on the need of pragmatism in stakeholder relationships as it becomes critical in today's global business environment. Myllykangas et al. (2010) 
demonstrated that stakeholder salience can vary from time-to-time in specific strategic periods and also, the salience model needs complementary insights to describe the relationship from the value creation point of view. Furthermore, additional characteristics are needed in order to go beyond the surface of a static classification to bring "stakeholder research closer to the business viewpoint" (Myllykangas et al. 2010: 70). The Stakeholder Relationships (SR) model is consistent with the aim of describing these relations according to the process of cooperative value creation (Freeman et al. 2007b). The model suggests six characteristics that have to be taken into account: (1) history of the relationships, (2) objectives of the stakeholders, (3) interactions, (4) information sharing (5) trust between partners and (6) propensity to learn (Myllykangas et al. 2010).

More recently, the work of Kujala et al. (2012) added a new perspective to stakeholder salience introducing the concept of dynamism, with respect to a turbulent situation. For instance, they demonstrated that in order to be able to retain its power, a company should actively seek ways to create and maintain multi-stakeholder networks instead of, or in addition to, concentrating on dyadic firm-stakeholder relations. The power in stakeholder relationships should be analyzed in relation to other stakeholders, as the network relations can boost the relative power of a stakeholder in a specific situation and context. Furthermore, when the focus of a stakeholder analysis moves from a static view of the firm-centric network to a network of relations, then a dynamic component has to be taken into account. Rowley (1997) presented a network theory of stakeholder influences examining reciprocal influences of stakeholders and the company. Moreover, when the process of value creation involves a community, like extended and collaborative enterprises, then the dynamic affects not only the way of managing diverging interests, but also the socioeconomic context become part of the achievement of the firm's mission (Saehs et al. 2002Post et al. 2002; Tencati and Zsolnai 2009). AQ3

Criticalities, dynamism, turbulence are facts affecting the business life via endogenous and exogenous influences (e.g. turbulence in the socio-eco-juridical context). Dynamism is herein defined as phenomena of matter due to the action of forces that requires the ability to manage these forces in a proper manner. In our case, the organization is placed in a social-economic context characterized by high rate of unemployment, disadvantaged young, criminality, new social needs, strictly inter-linked organizations. As such, the organization is timely dedicated to design its processes and its services, in order to answer to its stakeholders needs. Part of this dynamic attitude is reflected by its model of governance (i.e. to operate in networks).

At the same time, the adoption of innovative model of actions, for instance the network form, increases the complexity in governing the intra- and external- organization relations. A business network can be defined as a group of companies, which agree to cooperate in some way by sharing resources and decisions (Rosenfeld 1995), that differs from the definition of group (where different companies operate under a unique economic subject). Otherwise, a network should be formal or informal, such as multi-subsidiary firms, strategic alliances, industry-umbrella organizations, multi-party collaborations and stakeholder sets (Barringer and Harrison 2000; Harland et al. 2001; Jackson 2010). When the situation and the social context is dynamic, then the network for creating social value and social change should be extremely powerful. The network of social enterprises lets the mangers targeting efficiently the answers to social needs, using different configurations. The network has a strategic and social role, for instance involving public and private cooperation, engaging entrepreneurs (founders) and public and private institution (donors and partners) that feed, account and make sure that the societal goal are reached. Even though, the increased complexity implies intrinsic difficulties in evaluating those external expectations as there are several point of views: the network as a whole, each single entity or the relations between entities. In this sense, a static view of stakeholder management theory should be enriched by elements of dynamisms and networked-linked items. We propose a re-interpreted model of Stakeholder Management Theory (SMT) that includes the role of dynamism and networks, yet addressed by stakeholder salience and stakeholder relationships studies (Table 3.1).

Table 3.1

Essential pillars of SMT in relation to dynamism and network issues 
SMT1 The stakeholder salience can (or is likely to) change over time and space (Myllykangas et al. 2010)
Multiple point-of-views are required: network as a whole, each single entity or the relations between entities.

Stakeholder relationships are firstly subjected to internal network relationships (dyad, portfolio, connected relations, network) (Ritter et al. 2004).
Stakeholder Relationships model focuses on the

SMT2 role of relations in the process of cooperative value creation. The dynamism should increase the type, forms and strength of relations.
The stakeholder salience process should be constant over time. Strategies and consequences are not

SMT3 static but evolving. The information sharing is essential to set up strategies (Myllykangas et al. 2010).

The maximization of the well-being should take

SMT4 into account the extremely variance of the definition of "well-being" over time and space (included in SR model).
Set up strategies for managing stakeholder relations implies to clearly define the boundaries of the networks.

The absence of shareholders of the networks and the presence of multiple shareholders in the single entity requires a profound recognition of the mission of the network and its definition of "well-being".
There are moral issues also in stakeholder relations

SMT5 (Kujala 2001). These moral issues can imply to deal with multiple forces (i.e. contrasting, interlinked, implicit, explicit, etc.).
Multiple business operations intra and extra network should be subjected to ethical decision making processes.

Adapted from Signori and Rusconi (2009: 305)

In the next chapter, an interpretative case study will be shown. In this case, the researchers (the authors of the study) have taken part in the process of stakeholder recognition with the participants of the organizations involved. They observed the facts and interacted with the subjects. The article continues by describing the organization and its constituent parts. After that, a discussion of the methodology, participatory active research will follow. After that, the most important stakeholders are traced and discussed starting from a stakeholder salience model and evidencing the need to apply a stakeholder relationships approach in order to represent a situation under the dynamism. Then, a discussion of the main results and limitations will be provided.

\section{Research Context and the Case}

\section{The Context}

The case discussed is the one of an Italian social enterprise engaged in the field of early school dropouts that operates through different managerial forms typical of the Italian business environment (Corazza and Cisi 2012). It has been selected for its managerial complexity and of course, for its social impacts that influence the stakeholder analysis, as well.

As a proper premise, it should be outlined that this case study has been analyzed within the context of the Italian Economia Aziendale (EA) discipline. This approach has been studied in detail by Argandoña and von Weltzien Hoivik (2009) who defined $E A$ as the main academic theory of the firm used to describe the Italian business context. EA is a theory of business (or even better the azienda) with not only a strong economic content, but a ethical, humane, and social one as well (Argandoña and von WeltzienHoivik 2009). As such, from the beginning, the academic framework of Italian $E A$ has firmly rejected the separation between ethics and business. In that sense, the purpose of the business itself is the satisfaction of the human being and includes not only wealth creation but also the advancement of the human condition (Zappa 1962; Signori and Rusconi 2009; Costa and Ramus 2012). Signori and Rusconi (2009) have demonstrated that there is a strict interconnection between EA and Stakeholder Management Theory (SMT). In their holistic conception, the azienda plays a mediating role in harmonizing and composing diverging claims between stakeholders. In fact, the purpose of the firm is to "serve as a vehicle for coordinating stakeholder interests" (Evan and Edward Freeman 1993: 102). As previously mentioned: "the Italian Economia Aziendale masters may, therefore, be considered as implicit precursors of the stakeholder managerial theory, and their thoughts, 
without having pretensions of giving a definitive answer to crucial ethical questions still being debated, may contribute in a different way" (Signori and Rusconi 2009: 315).

$E A$ is taught at high schools, universities and managerial levels and it has contributed to the diffusion of a cultural background of managers that have encountered in their professional life the notion of socialità (envisaging the relation between external and internal stakeholders) and economicità (safeguard economic and financial sustainability).

The power of $E A$ is to influence the mindsets of managers towards an open and social vision of the firm that encompass the limited creation of value for the shareholders. These premises are important for depicting the mindset of the managers of our case independently to the nature of the business itself (i.e. social enterprise).

\section{The Case Study}

"Piazza dei Mestieri" ("square where people learn crafts") is a network of entities both profit, educational and not-for-profit, founded in 2004 by a group of friends with the aim of "doing something good for society". Piazza dei Mestieri is located in Turin, in north-west Italy and recently a new pole of Piazza was also open into a disadvantaged location in Sicily. The network deals with the problem of early school leaving, building a physical place where these disadvantaged young can learn a profession and, successively, find a job. The main building where the training courses take place is the same where the other entities are located and consists of a 7000 sq.m. court (in Turin the building is a completely renewed old factory).

The mission of Piazza consists of several pillars: (1) nurture talents, (2) educate people in design and aesthetics (3) innovate the professional training method, (4) support young people during the professional training and in appraise art, culture and sport, (5) educate people to be passionate about their work, (6) build networks.

In order to achieve its mission, Piazza operates through different separate legal entities, each one oriented to a particular purpose. The network is composed by: a foundation; four training agencies that work in partnership but not exclusively with Piazza (in traditional training such as hairstyling, cosmetic, hospitality, graphics, technicians); a cooperative that manage a restaurant, a brewery, a typography and a chocolate boutique. In addition, an association carries out all the cultural programs involving the young students as members (Fig. 3.1).

Fig. 3.1

The network of Piazza dei Mestieri

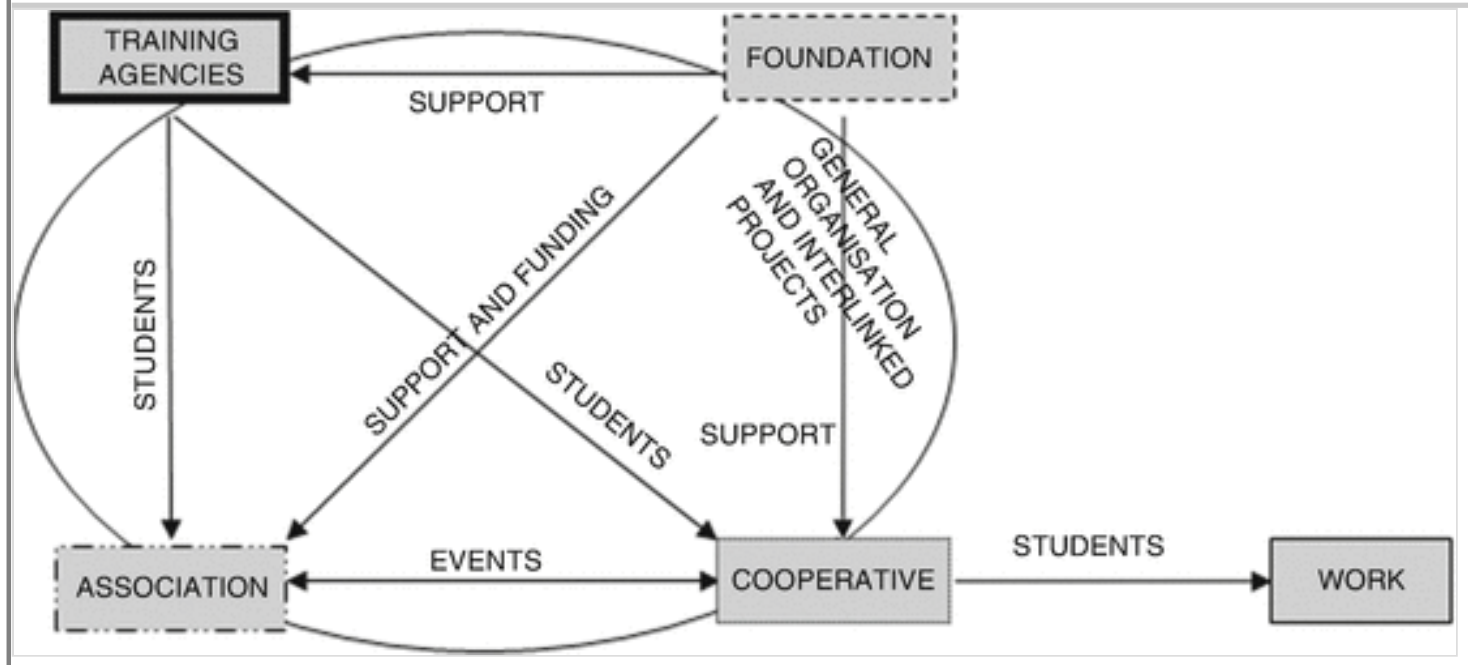

The foundation is responsible for managing the assets as well as for raising and managing funds. The training agency carries out all the training activities related to a specific subject while the cooperative manages the activities related to the business side of the model. The cooperative, for example, has the legal 
responsibility over the restaurant, catering, chocolateria, pub and brewery, and a work agency. The association involves the students in artistic and creative programs in order to "appreciate the importance of the beauty in the world in all the forms" (President of the Association, second interview).

In Italy, the percentage of early school dropouts is and still remains greater than the European average (around $17.6 \%$ in 2012, but the data was $20.8 \%$ in 2006 against a European value respectively of $12.6 \%$ and $15.3 \%$; source Eurostat data and elaboration of Piedmont Region Training Office 2013). Nowadays, the network of Piazza involves around 1000 students per year, 70 permanent employees and generates economic added value for EUR 5 million which is completely distributed and invested in the main training activities related to its missions.

In the last three years, the network model of Piazza has duplicated the training offerings including high professional skills in applied science, and, most important have created another network in Sicily. They also have created a stable partnership with training organization in Belo Horizonte (Brasil) to replicate the project. In particular, "the replicability of the model of Piazza is one of our main dreams. We aim to build a Piazza in every Italian city" (Founder of Piazza, first interview). Replicability means that due to legislative constraints, Piazza operates through specific agents in that case, each entities, with a precise purpose in order to maximize impact.

The innovativeness of the system relies on the school-work model. Students attend lectures and put theory into practice by working in laboratories, which provide service available to the public. The business units managed by the cooperative is in compliance with the most advanced qualitative standards and have been recognized by several prestigious international awards for food preparation and quality of service (awarded chefs, sommeliers and maitre are involved as lecturers and tutors). In addition, all the cultural events carried out by the association are free and open at the public.

As 2014 was the decennial of Piazza, the managers decided to start a process of stakeholder dialogue to account the progresses made in the last ten years and for the future developments of the model which is currently carried out also in social contexts not near the original location. In order to adapt the model to different socio-economic and cultural backgrounds, the managers of Piazza decided to start a stakeholder analysis project to identify those strategic processes of engagements that can be replicated in different contexts at different time. In the case of Piazza, the dynamism is present in the business sector (high percentage of unemployed young and school leavers) and the social problems linked to it, the socio-ecocultural context (different regions and countries) and the managerial practices in-between and outside the network.

The case reported will be narrated though the use of a participatory action research, where the researchers (authors of the study) have taken an active part of the entire project.

\section{Research Methods}

Action research is a qualitative, but positivist research design aimed at testing the efficient application of a theory or the evolution of a theory in a proper manner. As active, there is an interactive involvement in complex social context where a change or an intervention occurs and the outcome of such modification is the phenomena analyzed (Whyte et al. 1989; Whyte 1989; Eden and Huxman 1996; Dickens and Watkins 1999). In this method the researcher is directly involved in testing the effects of a theory-based action and in explaining if, and how, such effects validate the theory under consideration (Greenwood and Levin 2007; Bhattacherjee 2012). The purpose of action research is to learn through actions that are grounded to personal or professional development. Action research is participatory in nature Kemmis and McTaggart (2000: 595). Participatory Action Research (PAR) has been implemented in business and management practice only in recent times (Cassels and Johnson 2006; Coghlan and Brannick 2014). Different models explain the action research process, among the others are the Kemmis and McTaggart's spiral (2000); the (O'Leary 2004) cycles of action; the Elliot's action research model (Elliot 1991). As commented by Koshy et al. (2010), all the models share some common futures such as: "a better understanding, participation, improvement, reform, problem finding, problem solving, a step-by-step process, modification, and theory building” (Koshy et al. 2010: 10). In this paper, we use the rationale developed by Susman and Evered (1978), in order to give to the reader a clear and simple overview of the PAR and its practical application. Following this, an action 
research cycle consists of five phases: (1) diagnosing, (2) action planning, (3) action taking, (4) evaluating, and (5) learning.

For instance, Battaglia et al. (2015) have used this methodology in order to conduct a longitudinal study of a cooperative firm involved in social reporting and corporate identity activities.

With the aim of reaching particular social changes, as those required in Piazza (i.e. identify, manage, and engage stakeholders effectively), the researchers/authors of this study suggested the implementation of a PAR methodology during the work in Piazza. The research activities started in March 2014 and end in July 2014.

PAR process starts with a diagnostic phase. Usually during phase 1, a problematic situation is identified with particular references to a social context. This means interpreting the organizational shapes of the problem avoiding simplifications and reductions (in our case the identity of the network was the main problem) (Eden and Huxham 1996). During this phase (March-April 2014), the researchers/authors visited the location of Piazza during the school and after-school hours taking photos, talking with the students and looking to reallife moments. Researcher/authors joined the cafeteria and pub, the work agencies and the secretary office of the training agencies anonymously for most of the time seeing with their own eyes the meaning of "turbulent environment" (disadvantaged families and students with their really impressive expectations and problems).

Action planning (phase 2, April 2014) involves identifying and evaluating alternative solutions to the problem, and deciding on a future course of action (based on theoretical rationale developed in phase 1). After phase 1, a reflection over the Piazza innovative system was needed. The need of setting up the boundaries of Piazza, define the existing relations and of Piazza stakeholders' expectations, was of paramount importance. During this phase, we conducted several interviews and we encourage Piazza mangers to draw a sort of Piazza map.

Phase 3 of PAR deals with action-taking which means implementing significant change to improve a situation. In Piazza (May 2014), the researchers/authors puzzled over the complex intersection between mission, values, purposes and the stakeholders of each organization that compose the Piazza network. Researchers tried to disentangle the relations between foundation, training agencies, cooperative, association and joined some Piazza's activities (mostly pub and cafeteria).

Phase 4 examines the extent to which the initiated action is successful in resolving the original problem (evaluation stage). During this step, the outcomes of the previous action implemented are evaluated in a critical manner and referred to practical effects achieved. After pinpointing the importance of the mission, the contribution of each subject and their relations for the overall sustainability of the Piazza's system, the researchers/authors co-worked with Piazza managers to define the salience of their stakeholders (June 2014). Phase 5 (July 2014) is considered the learning stage: during this phase the members of the project reflect on the findings, trying to learn lessons and create new knowledge (understandings, skills, and values). This process is a continuous cycle which means that after phase 5 the entire process can restart.

During the project, we joined numerous meetings with the board of the entire Piazza's network and collected information. The data were collected through personal interviews, plenary meetings and moments of coworking with managers and operational staff of Piazza. A distinction between personal interviews from plenary meetings and moments of co-working have been made in order to report the most real situation. In total, there were: 10 direct interviews to managers and directors and 2 plenary meetings (Board of Directors).

The length of an interview was a minimum of $0.5 \mathrm{~h}$ to $2 \mathrm{~h}$; while, the plenary meetings lasted $3 \mathrm{~h}$ each. The transcription of the interviews and other notes comprises over 300 pages. The moments of co-working have been set up in order to observe moments of life in Piazza (5 days). Additional sources of information were: internal documents, stakeholders' documents used in specific cases of communications (specific reports between donors and foundation), external press release, and, the work of Ragazzi (2008). In 2008, Piazza dei Mestieri published a scientific book authored by Ragazzi, a researcher from National Research Council with the purpose of replicating the model in other geographical contexts. 
The data collected have been analyzed codifying pictures and video related to events, and, apart, the transcription of the interviews have been analyzed using graphs. All the quotations have been translated into English by the authors, selecting those words and sentences that do not change the meaning of the original Italian version. The analysis of the transcriptions consisted in marking segment or a quotation of an associated document, and the graphs have been made generated using a cause-effect analysis application (Mental Modeler) for mapping the logic of the sentences. In our approach, we have analyzed one sentence at a time following the rationale of $\mathrm{A} \rightarrow \mathrm{B}, \mathrm{B} \rightarrow \mathrm{C}$, then, $\mathrm{A} \rightarrow \mathrm{C}$. We reported also the negative sentences, or the contradictory ones. Researchers have double read every part of the documentation collected in order to have a double check over the meaning and the importance of the information for the research. A detailed work of commenting and labeling the sentences have been performed on the interview transcriptions with the aims of carefully safeguarding the true meaning of the interviewees and contextualizing. The participations at the Board of Directors have been of importance for the research as we have assisted to the original organizational and personal behavior of the entire management of Piazza (tone of voice, posture, words, etc...) and we related them to the internal hierarchy.

The timeline of the interviews and some information on the profile of the interviewees are reported in the table below (Table 3.2).

\section{Table 3.2}

The timeline of interviews conducted in Piazza dei Mestieri

\begin{tabular}{|c|c|c|c|c|}
\hline $\begin{array}{l}\text { Interviewed } \\
\text { organization }\end{array}$ & $\begin{array}{l}\text { Interviewed } \\
\text { persons }\end{array}$ & Type of action & When & Where \\
\hline Foundation & $\begin{array}{l}\text { Director of Piazza } \\
\text { (Man) }\end{array}$ & $\begin{array}{l}\text { Interviews (3) E-mails (from } \\
\text { March } 2014 \text { to July 2014) }\end{array}$ & $\begin{array}{l}\text { Interview } \\
\text { Director: } \\
\text { March } 2014 \\
\text { April } 2014 \\
\text { May 2014 } \\
\text { Interview } \\
\text { Founder: May } \\
2014 \\
\text { July } 2014\end{array}$ & $\begin{array}{l}\text { Inside his office in Piazza } \\
\text { At Piazza's restaurant } \\
\text { during the service Virtual }\end{array}$ \\
\hline & Founder (Male) & Interview (2) & & \\
\hline $\begin{array}{l}\text { Training } \\
\text { agencies }\end{array}$ & $\begin{array}{l}\text { Founder (Female) } \\
\text { Manger of training } \\
\text { activities (Male) }\end{array}$ & Interviews (2) & $\begin{array}{l}\text { Interview } \\
(\text { Co-): March } \\
2014 \\
\text { May } 2014\end{array}$ & $\begin{array}{l}\text { Inside the President of the } \\
\text { Foundation office } \\
\text { At Piazza's Pub during } \\
\text { the service }\end{array}$ \\
\hline Association & $\begin{array}{l}\text { President of the } \\
\text { Association (Male) }\end{array}$ & Interview (1) & $\begin{array}{l}\text { Interview: } \\
\text { March } 2014\end{array}$ & $\begin{array}{l}\text { Inside the President of the } \\
\text { Foundation office }\end{array}$ \\
\hline Cooperative & Manager (Male) & Interview (2) & $\begin{array}{l}\text { Interview: } \\
\text { March } 2014 \\
\text { May } 2014\end{array}$ & Inside his office \\
\hline
\end{tabular}

\section{Findings}

With the aim of presenting and deriving useful insights that emerged from our project, the activities performed are described using the lens of PAR. This methodology of presentation expresses the main activities performed and underline those aspects that have stimulated a heated debate in the complex network under study. As such, in the study the word "researchers" refers to the role of the authors involved in the research project.

\section{Diagnostic Phase}


The first level of the research process was the analysis of the issues related to the self-reflective period which the entire Piazza's organization was experiencing. As reported before, in 2014 Piazza's network celebrated the first decennial of their activity. The original founders of Piazza were afraid of the evolution of the inside and outside dimensions of the network including the mind of those people actively involved (founders, owners, managers, students etc.), and the opinion of those entities and people that join their activities from an outside perspective (donors, institutions, etc.). In the first meeting with the Director, the main issue discussed was the emerging need to adopt a management sophisticated tool to communicate internally and externally not only the last ten years of activity, or the need of receive additional grant and funds, but solely the structure of Piazza's network. At the beginning of our research activity, the Director of Piazza was reflecting about the opportunity of being involved into a social reporting activity. In the case of Piazza, the decision of being engaged into a process of systematic collection, elaboration and representation of data and information related to sustainability was immature. In addition, the attitude of the top management of Piazza's network towards the researchers was initially hostile.

At the very beginning, a suspicious attitude towards the involvement of researchers in hot spots discussion was manifested. Then, after the first meeting with the Director, the attitude of all the staff involved in the project rapidly changed and they became more cooperative and passionate. After a first day of quick interviews with the top management (10 managers), the researchers inferred that the real main issue was that: the evolution of Piazza after ten years of activities let the people proud of their work, but also too focused on their daily routines. People were forgetting the great pictures initially in mind of the founders. In that sense, the diagnostic phase ended with the identification of the real problem: what was Piazza after 10 years of activity? This important question arose before any kind of debate around who the interlocutors of Piazza are. Because a network may influence and be influenced in various way by its interlocutors, the main mission of the network itself must be transparent and clear to all the entities involved. Furthermore, even if the main activities of Piazza are located in the same physical space, every piece of the network was governed by specific values and features. For instance, the Director used to say "we are physically in a container that works as a hub aimed to heal the wounds of the external reality" (Director of Piazza, first interview). During this diagnostic phase, PAR progresses from problem solving to problem posing, emerging those issue addressed in the next stages. In that sense, the researchers found useful insights from the work of Kujala et al. (2012) that addresses the main issue of stakeholder salience in complex networks. Clearly, before examining the main stakeholders of Piazza's network, a systematization of the identity of the network should be provided. The process of editing a sustainability report for Piazza was not the main issue, but only the Trojan horse for deeper reflection.

\section{Action Planning Phase}

In order to set up a plan of actions aimed at applying an "advanced" stakeholder salience model (i.e. network representation), some pinpoints have to be identified and a definition of Piazza's network has to be outlined. This action was the first action implemented by researchers, because a definition of networks is needed in order to identify those entities that are actively part of a network, those entities that are partially part of a network, and, those entities that are not part of the network even if they share commonalities (e.g. the case of a training agencies providing additional courses for adults and professionals).

As mentioned above, as the Piazza activities are extended also in another Italian region, the geographical location of the activities was not a possible criterion to be applied. In this case, a process of reconstruction of the identity of Piazza has been made. In particular, the researchers asked the Director of Piazza to draw a picture of the network and, once the picture has been drawn the other participant of the group provided their insights and variations.

Figure 3.2 is a graphical representation of the Piazza networks in two regions. In particular, "the replicability of the model of Piazza is one of our main dreams. We aim to build a Piazza in every Italian city" (Founder of Piazza, first interview). The circles that intersected the outside environment represent those entities that partially joined the Piazza networks. They are mainly training agencies that also provide additional services for job recruiting and candidates' selection. For instance, a training agency can offer additional activities on the market and at the same time be responsible of courses in Piazza. The human resources (staff, lecturers, teachers, educators) working for the training agency are called to act as Piazza representative as they are teacher. This means to share the moral value of the network during their routine activities, even they teach 
also in courses outside Piazza. More deepen, even if other entities under the official control of the foundation exist, the Piazza involves only those entities represented in the figure. In that sense, one of the main criticality of Piazza was to define who is in and who is out. This task has let both researchers and managers to conclude that after ten years of activity a moment of reflection on Piazza were necessary. Then, considering that after phase 1, the main problem of Piazza shifted from the need of a social account to an identification of what Piazza was after ten years, the alternatives were clear. A simplistic application of a consultancy approach would have not been effective because the organization of Piazza is fragmented and each entity reflects a particular sub-purpose, with its own values and interlocutors. Even though, a reflection over the Piazza's stakeholder framework seemed to be necessary and fundamental, a suitable sophisticated approach was needed (on stakeholder management of complex networks of entities).

\section{Fig. 3.2}

The composition of Piazza's network

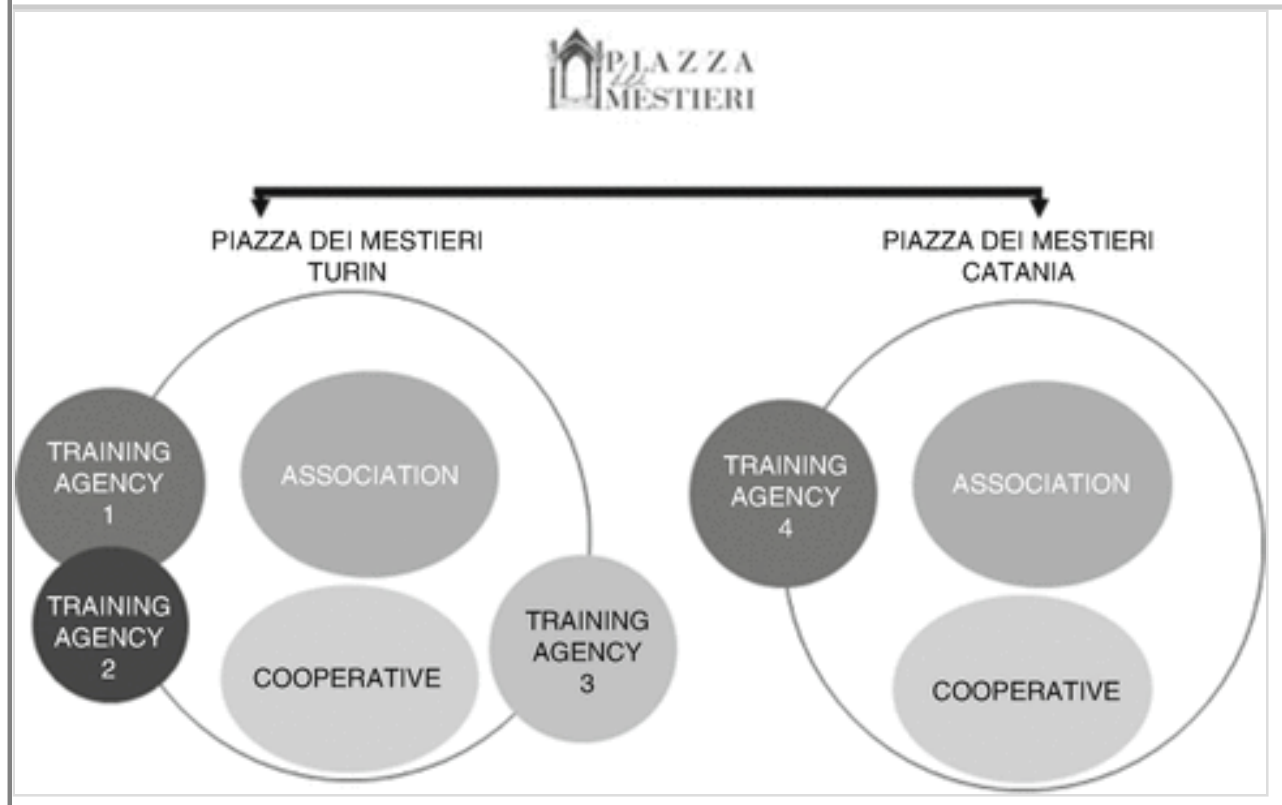

In this phase, the researchers provided some insights on how to set up a functional plan, and especially they stressed the importance of: (1) having face to face interviews with the managers and staff representatives included in the picture; (2) approaching the argument of the "essence of their role" in Piazza's mission; and (3) having a general discussion over their main interlocutors.

\section{Action-taking Phase}

In the action-taking phase, the researchers performed one by one interviews of the top management. These interviews were conducted in a private environment without external influence of factors, like other participants of the projects, other employees or students. The first issue under consideration was the role of each structure in reaching the main purpose of Piazza. As reported before, the Director of Piazza affirmed proudly that the foundation exerted a role of "box" and added that the replicability of the training model represents the success of the all Piazza's network. In addition, the Director opened up new perspectives and scenarios affirming: "we must give an answer to young people needs, trying to carry on the initial dream of our founders" (Director, second meeting). In that sense, the founders themselves exert a non-institutional pressure on the Director. Furthermore, the Director confirmed, "we are a sort of antenna, we can read the signal directly from our territories and communicate information and problems to public authorities. We can recommend public policies as we look at reality from a unique perspective"; and obviously, "my role is to be carefully engaged in all the partnership that can add value to our network in terms of funds, resources, visibility and institutionally and can be translated into additional scholarships funding" (Director, second meeting).

As the innovative training system consists of practical activities after the traditional training sessions, the researchers decided to involve in the discussion both the director of the training agency and one of the 
original founder of Piazza that represents also another training agency. In these discussions, another shade of the role of Piazza came up. "We deeply care about the training success of our student. We have a moral role. We involve disadvantaged young people that usually have a negative experience with traditional schools; our role is to give them a renovate trust in training institution" (Training manager, second meeting). As confirmed in one of the internal document of Piazza, the role of educators is to read and interpret the need of young people. Starting from a precedent analysis of Piazza's student welfare, these needs are: emotional and relational; related to self-esteem and self-evaluation; motivational, in order to contrast the drop-out from the school system; and of guidance, i.e. the need to have a person (usually a teacher) who can direct them during their training life.

The fact that Piazza operated in a critical district is confirmed by the words of one of the founders: "every year Piazza deals with a problematic situation, as we have more applications than positions available; that implies setting up a screening based on motivational interviews, aptitude tests and dialogue with families or social services. When we have to refuse an application, for us it is a failure; but, legally we cannot accept all the applicants" and also "we invest our time in drawing a precise individual project for each of our students in order to empower them and be ready for a job" (Founder and Training manager, second meeting).

The operations manager of the cooperative of production and work (manager of the business unit previously mentioned), brought another perspective "our business activities are a gym for our students; they can learn and apply their knowledge in a real firm. For instance, we do not inform our customers of our business model. We do not tell our restaurant customers who our waiters are, who produce the beer, who cook our meals. All of our trainers have a great reputation, our products are internationally awarded and all of our locations look exactly alike. Our customers should buy our products not for our business model, but for the value of the product itself" (Operation Manager, second interview). "We have a clear production plan, we program our business activity as all other manufacturers do, we have a sales target and we are present in the market with our brands, we have a margin and we get profit" (Director, third meeting). In these two sentences, the entrepreneurial soul of a social enterprise reveals.

Finally, the President of the association provided other prospects on the Piazza's network: "The purpose of the association is to promote the culture of beauty, to develop creative skills, to help our students become open-minded and positively engage our local community in our activities" (President of the association, first meeting). The purpose of showing the potential of the art in increasing the self-esteem of students and showing them the beauty of life, even in a turbulent district, is the mission of the association.

During this phase, the researchers conclude a need to apply a face-and-name approach with each managers and go beyond the surface of the stakeholder-as-a-label to identify and describe the relation.

\section{Evaluation Phase}

When a network of firms is engaged into an activity of self-reflection, distinct and antonym values, missions and behaviors can be discovered. In this case, the distinction between purpose driven entities and income driven entities becomes real. Evidences of different perceptions of the role of Piazza have been recorded. The researchers discussed in plenary the results of these actions agreed about the evolutionary process that Piazza was performing. After ten years of activities, Piazza discovered new needs, new stakeholders and new expectations. After a first round of interviews, and the collection of the materials, the work of researchers focused on involving the participants around a first identification of the main interlocutors of Piazza (as reported in Annex I). Researchers composed the results of the interviews by editing the table in Annex I. The table represented the first output of the research project and it was used in order to give a preliminary feedback to Piazza's managers on their research work as the managers involved were looking for a practical feedback derived by the research activity. The final table is a merge of different and separate sub-tables, one for each entity interviewed; and each sub-table has been commented and reviewed by other interviewees. During the research process, the table became of paramount importance to have a clear snapshot of Piazza and a term of reference in case of misunderstanding.

We looked at each organization, asking the interviewee to start a sort of "stream of consciousness". During this dialogue, the researchers asked to define the history of the relation, the objective, the type of the interactions and the information shared, whether there were moral values involved and mutual 
understanding. We decided to put a focus on the nature of these relationships they represent the core of the entire process of value creation of Piazza. Even if this approach seems to be manipulated by researchers, for the most part the interviewees showed a confident attitude in identifying their interlocutors.

As reported in Annex I, students are the main stakeholder cited by all the managers of Piazza. The table reports only that information collected and analyzed through the interviews and only for those elements explicitly stated. Every transcription of the interviews has been divided in sentences and the sentences have been grouped by information related to the description of the relationships and the expectation of the stakeholders under Piazza point of view. In Fig. 3.3, we draw up a graphical representation of Piazza's stakeholders stressing the relations between each entity and its stakeholders. Then, we included all the entities of Piazza at once.

Fig. 3.3

Piazza dei Mestieri and its stakeholders

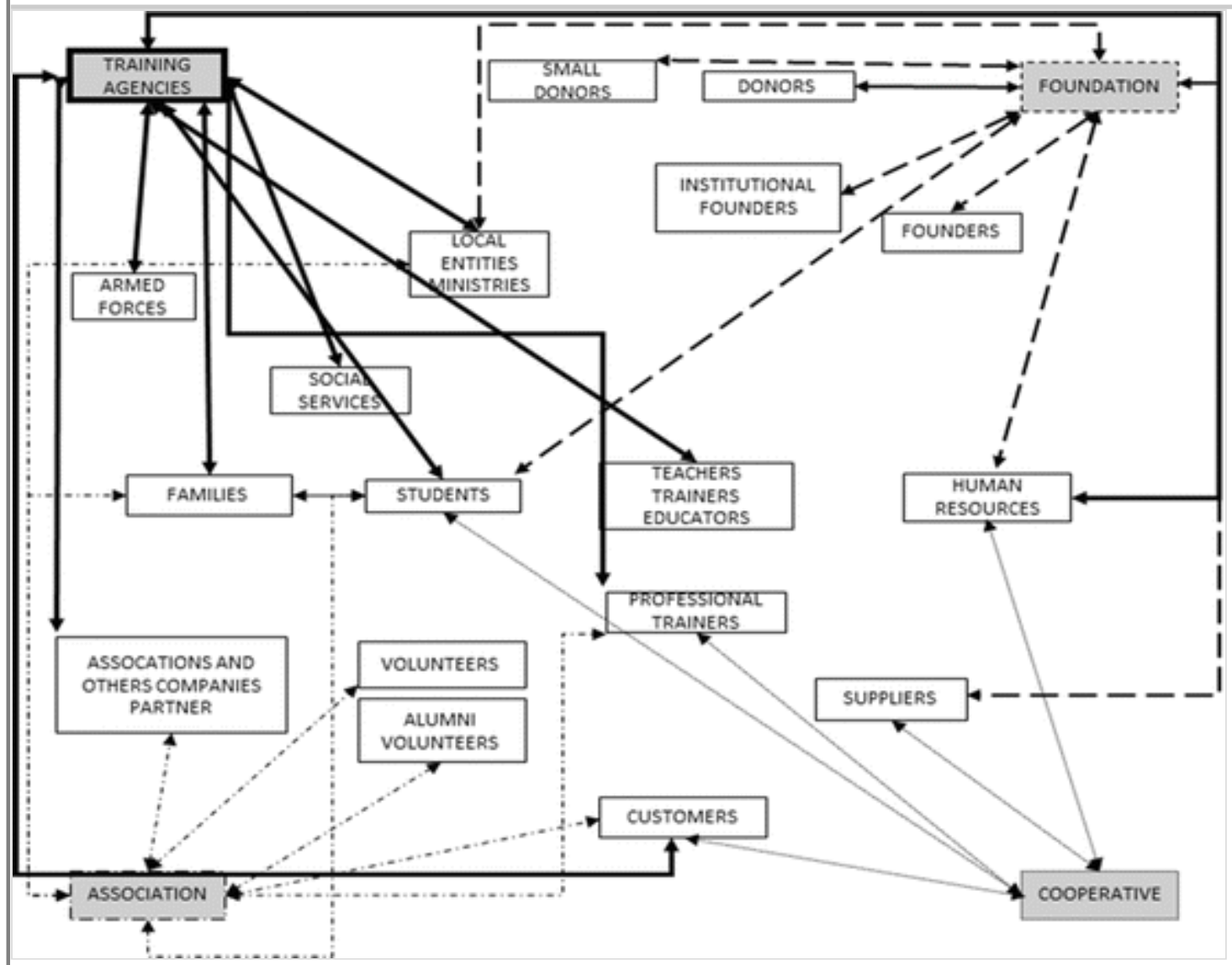

As it can be noted reading the table in Annex I, the complementarity among stakeholders is evident. In our case, the different organizations that work in Piazza, have a "principal" stakeholder recognized under "student" category. Even though, we found sometimes-counterproductive relation between Piazza-entity and stakeholders, and sometimes the relation seemed not to exist at all. There was a tendency to recognize as stakeholder only those categories of subject "closer" to the activities of each entity. For instance, the President of the association does not recognize as "customers" those people that join Piazza's events, otherwise, the stakeholder "family" is excluded by most of the interviewees, while the representative of teacher posed additional "salience" on that category. This happened as a result of the networking system. In a group of different entities, each part of the group tended to focus on their daily interlocutors and not looked at Piazza as a whole. Referring to practical effects achieved, the members of this experimental project stressed the need to make a step towards a deeper understanding of the relation between stakeholders and Piazza's organizations. The last phase of PAR is the learning stage, in which members of the project capitalize on the knowledge acquired and create new knowledge (Susman and Evered 1978).

\section{Learning}


Derived from Phase 4, a persistent need of clarifying the relations between stakeholders and Piazza became increasingly important. In order to give the reader a trustable presentation of the case study, honestly, during the conversations and interviews some of the elements came up spontaneously. The propensity of retrace the history of the relationships between Piazza and a part of their stakeholders is a case in point. In addition, to demonstrate the importance of an open discussion over stakeholder analysis, a plenary meeting was established. During the plenary meeting, two of three original founders of Piazza discussed the entire work done and again, they underlined the importance of a "self-reflection moment that is not a self-celebration, but a discussion over the importance of cooperating together to improve the entire welfare system" (President of the foundation, extract of the social report, 2014). Another founder also confirmed the concept of systematic cooperation towards a general improvement of living, studying and working conditions of the people who join Piazza. She said: "my dream of one Piazza in each city of the world is even truer, but our force is the force of all those people that are able to collaborate and cooperate. We would like to share our innovative methodology with all the people interested" (Founders of Piazza, first plenary meeting).

In stakeholder theory literature, Kujala et al. (2012) stressed the importance of the network of relations, as well; but the application of network relations in a critical environment is quite complicated. The researchers produced a sort of Piazza stakeholders' network in order to identify precise links between subjects.

Obviously, the internal organizations of Piazza are strictly interdependent and interrelated, and this links are not herein presented. Even though, in Fig. 3.4 there is a preliminary representation of the interrelations between those stakeholders important for Piazza as the network relations can boost the relative power of a stakeholder in a specific situation and context.

Fig. 3.4

Links between Piazza's stakeholders

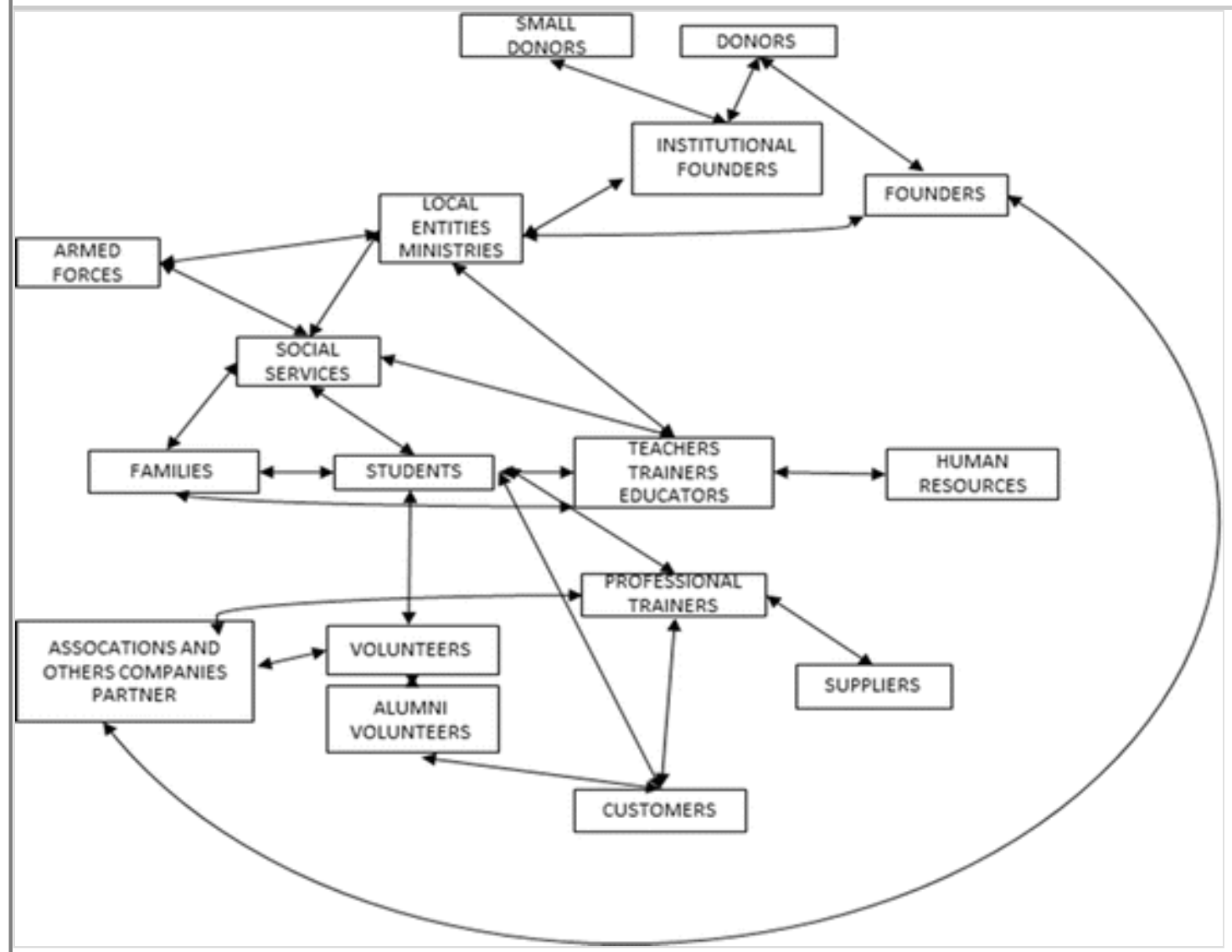

As mentioned above, Piazza can be defined a turbulent environment because of the presence of: multiple subjects that act as a network; multiple stakeholders' relations; a strong orientation towards common goods, solving social problems and public welfare; innovative training system that involve public, private, for profit and for benefit entities. Thus, it is logical to affirm that even Piazza networking activities, each part of the 
overall system has typical and specific stakeholder relations. Figure 3.5 represents the links between Piazza and its stakeholders; each color represents the relations between each member of Piazza and its stakeholders.

Fig. 3.5

Piazza's stakeholder network

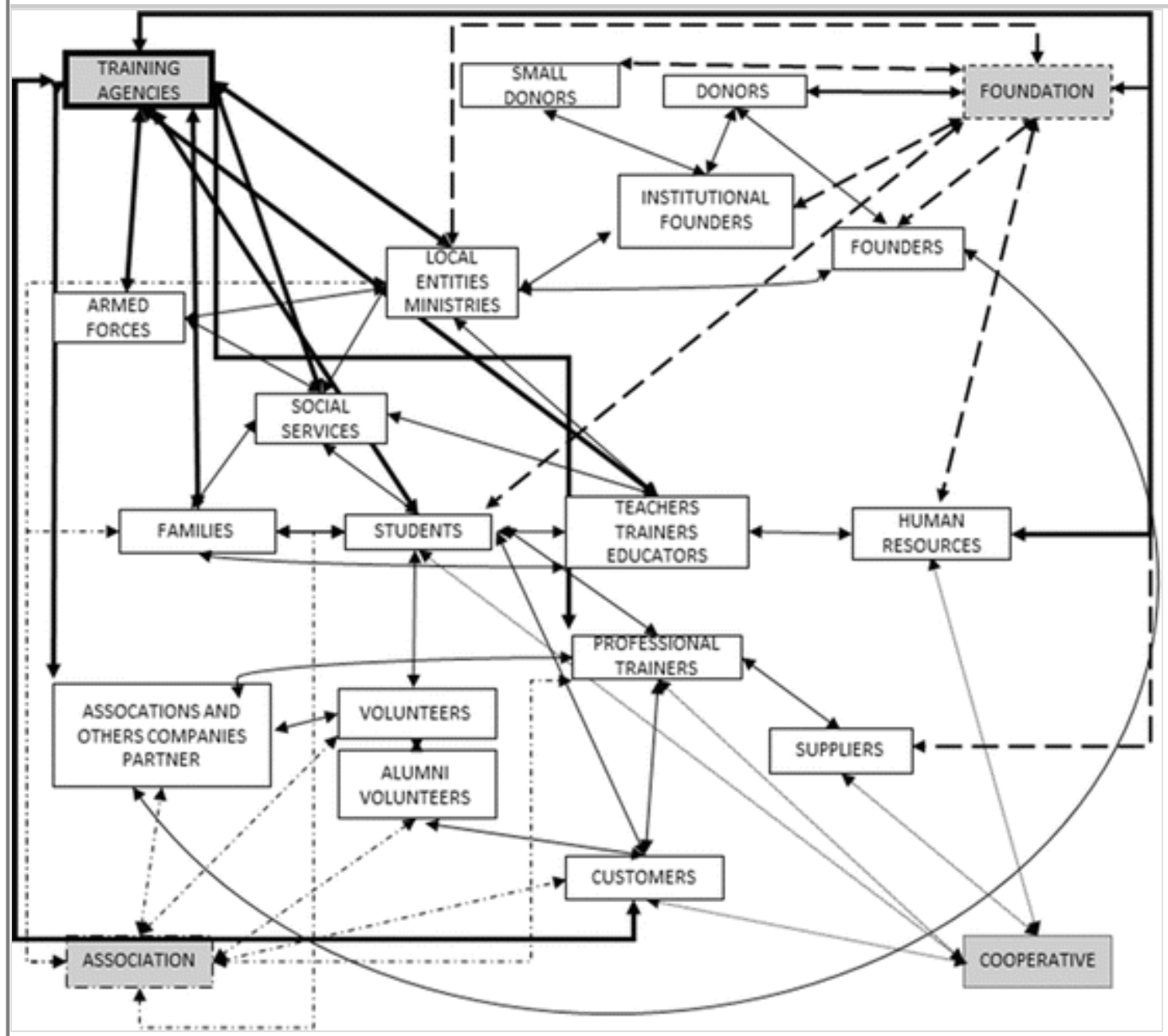

As a conclusion of Phase 5, new knowledge has been created. First, the importance of stakeholder's identification as a process of self-reflection. Second, the importance of self-reflection over the overall mission and purpose of the complex system. Third, the network analysis of stakeholders was useful in order to determine to what extent a social report will be edited for and especially what information should be included in order to meet materiality needs and stakeholders' expectations. In addition, after Phase 5, Piazza's governance decided to make some hypothesis on how to improve the engagement between stakeholders and Piazza, not only through accountability process. For instance, Piazza decided to put efforts in involving families in daily routines, and define strategic paths for increase the importance of the association. As a point for future improvement, an analysis of the time dimension of stakeholders' network, and a space dimension such a geographical expansion of the network should be provided; that will be important in order to replicate the model into another geographical context.

\section{Discussion}

\section{Managerial Implications}

The stakeholders' relational mindset has numerous managerial implications. For the sake of convenience, we refer to strategy, and in particular of leadership and organization. Strategy is a dynamic organizing process that involves both formulation and implementation of contents and processes, planning and actions. Often, alongside the intentional strategy, organizations must deal with unexpected episodes, while managing capabilities and resources. The stakeholders' relational mindset requires the ability to construct and to 
manage the relationships formed by the organization using distinctive skills, capital and infrastructures. The network of entities and the network of stakeholders are interconnected, in terms of relations and people. Of course, people working in the network should be aware of the organizational layout of the network and they should improve their dynamic capabilities. These dynamic capabilities are, for instance, the internal relational skills of co-operation between other poles of the network, ability to share external contacts within the network, ability to offer an external view of the network that should be coherent with those offered by other members. As a consequence, those who lead the network should have the ability to represent the entire network and carefully manage the relational resource (and of course the financial ones) collected in order to maintain the sustainability of the entire network, and at the same time, to nurture the single entities in the proper and strategic manner.

For instance, in the case of powerful external stakeholders like financiers or donors, the leader must present a unique picture of the network and how the resources collected will be allocated according to the network needs. Offering outside stakeholders, a coherent scenario of values is therefore essential. The values of a relational mindset dictate going beyond the single entity and beyond a myopic view of the short-term period to serve the network welfare. These values may be about social impact of the entire network, quality of the services provided, innovation in the business model, new training practices and processes. Obviously, the leader needs to foster a mindset and an environment where everyone works cooperatively for the networks objectives. On the other side, stakeholders will be confident in confer their resources (their stake) to a coherent organization. If, for example, each entity moves like single-runners, the overall wellness of the network is compromised. Simultaneously, the presence of different entities belonging to the network represents a strategic leverage, as the leader of the network could play different games at his convenience (for instances, in order to start a dialogue with one stakeholders he should suggest to present the network through one entity or another).

Finally, the greater the network of stakeholders, the greater the managerial issues. In this case, the leader, as the vertex of a network must know every stakeholder and, should have a direct contact with each of them.

\section{Theoretical Contribution}

As stated by one of the most important authors of the entire $E A$ discipline, the azienda as a system is open to external dialogue and the system, as such, has a greater value due to its completeness and perfection, based on intangible assets (Ferrero 1987). Among these intangible assets are the stakeholder relationships expressed as a form of social capital (Garriga 2011) that can be managed in a proper way.

The objective of this study was to contribute to the body of stakeholder literature by providing a complete analysis of the dynamics that naturally occur in a network of entities during the process of analysis of stakeholder relationships. The study demonstrates that this process is highly fragmented when an entity operates through a coordinated combination of different firms (with several legal entities) forming a network. In our view, the main relation is between a network of entities and its stakeholders and there is an implicit need of tools to describe and analyze this complex environment. This study demonstrates the effectiveness of the stakeholder relationships model in complex environment as it properly describes the relations between stakeholders and entities as a source of social value creation. Moreover, stakeholder thinking can turn out complicated when the overall purpose of the network is to provide social goods for increasing social welfare in a turbulent community.

This study also suggests that the stakeholder relationships model is important when the structure of the value creation process is not pivotal on one way (bi-univocal firms-stakeholders relation), but when several counterparties influence the entire structure (stakeholders interrelated with themselves and with the network).

In this case of Piazza dei Mestieri, the general social purpose is successfully achieved through a network of entities and the first contribution of this paper is to stress the importance of the overall network orientation in achieving the mission and uniformly sharing the vision. Second, through the direct observation of the phenomena offer the possibility to collect genuine data (Susman and Evered 1978; Cassels and Johnson 2006; Coghlan and Brannick 2014). In addition, it can create new knowledge, consciousness and engagement among people involved. It should be noted that in our case, the transparency and correctness of the members of Piazza was crucial in order to produce also new scientific contribution. Third, the discussion of the 
relationships between the network and its stakeholders is a replicable process that every network can apply (for instance in a supply chain, or in a district or in an association). As such, the paper provides guidelines on the process and the steps through which the project can assume an effective application.

\section{Limitations and Future Research}

PAR methodology is subjected to personal influence of researchers and people involved in the project and in order to limit the risks of affecting the data the research team used to compare the data once collected (Coghlan and Brannick 2014). The main limitations of the PAR are due to the essence of researchers' participation into the research project. While traditional research models apply a passive research approach, PAR constitutes a shift by emphasizing the fundamental importance of experiential knowledge (Brown 1985). On one hand (traditional research models), researchers stand outside the community to have a whole perspective of the research problem. On the other hand (i.e. PAR), researchers stand by to record the real situation about the community and research subjects (Eden and Huxman 1996). This can influence the overall outcomes of the research, as researchers are proactively involved in the project and may influence the direction of the project's results (Reason and Bradbury 2001). In our case, in order to avoid the risk of influence the results of the project, researchers have involved an independent auditor (selected among people who knew Piazza's history and without a personal involvement in the management and in the project itself). The involvement of a third-party has been fundamental for the final outcome as in PAR there is the risk of unacceptability of the researchers in the group. Another risk related to PAR is due to the provenience of the researcher (Darwin 1999). Different backgrounds have different external manifestations on people's languages, body languages and behavior; there is an implicit difficulty for a researcher to get well involved in a group, especially if the researcher comes from a different background (university vs. high school). In order to avoid eventual misinterpretation of the results, researchers have discussed the data collected with the external consultant.

In addition to PAR, the paper illustrates a single case study that may conduct to an intrinsic limitation, i.e. the context in which Piazza operates. Different cultural background and different socio-economic issues may affect the generalizability of the results as social problems are usually strictly interconnected to the social background (i.e. the results may greatly change in the same city, or same region). Conversely, the paper is not aimed at just illustrating the case, but it shows a sort of process that should be replicated and generalized by those organizations that operates in a network with different purposes and different profit or mission orientation.

Further research may be undertaken in order to test the instrumental aspects of this model and to compare the point of view of the subjects with the inner perspective. Moreover, stakeholder relationships model imposes new skills and sensitiveness in the way the relations with stakeholders are managed. New studies on the effective of stakeholder relationships on business strategy on the influence of stakeholders in the process of creation of social value are needed. The creation of social value is herein intended as the creation (and likely, maximization) of the positive social impact over society and environment. In that sense, how stakeholder relationships model can help organizations in setting strategies to creating positive social impacts and how these impacts are shared by the network (for instance, we state that there is a difference between stakeholder management strategy towards contrasting early school leavers and stakeholder management strategy to guarantee a high rate of employability to students). In that sense, we suppose that further studies on the role of stakeholder relationships for managing social impacts can bring new insights to existent literature. Kujala et al. (2012) demonstrated that in complex and turbulent environment, conflicts and problematic situations can occur and building of a common ground on mutual understanding is essential in setting a co-operative nature for joint value creation. To sum up, managers and practitioners that work in a network of entities should take into account the importance of stakeholder relationships both in their own field and in the system as a whole (for instance, there should be differences between profit and not-for-profit context). In fact, this way of comparing, reflecting and engaging is the only effective way to co-create social and economic value in the networks era.

\section{Conclusion}

The purpose of this article was to investigate the process of stakeholder relationships into a network of different legal entities. The article presents a case study of a network of organizations that provide training 
and work possibilities to early school leavers in a critical socio-economic context working principally with young disadvantage people. Applying a practical research methodology, the participatory active research, we applied stakeholder relationships model to our case and in the meanwhile we supported the organization examined with practical insights. We investigated the stakeholder's composition, the relations between subjects in the network and outside the network, as well.

The study contributes to literature on stakeholder management by stressing the complexity of stakeholder relationships and its dynamism, including the paramount importance of the context. Our analysis can offer contributions and insights to all those organizations that operates through formal and informal network and they need to compose their interests and share them for a common purpose. In particular, our case refers to a mission-driven network where the maximization of a positive social impacts can effectively contribute to the well-being of the society.

Based on our case study, we analyzed different perspective of analysis, on one side the inner perspective of the single entity and suddenly the broader network. We demonstrate that managers who want to apply stakeholder relationships model to set up proper management strategies need to acquire new skills and knowledge. As a result of our analysis, the dynamic capabilities are, the internal relational skills of cooperation between different poles of the network, ability to share external contacts within the network, ability to offer an external view of the network that should be coherent with those offered by the members, represent a transparent and trustable reputation to different stakeholders, manage stakeholders' relations to increase the positive social impact creation. Further research in profit and not-for-profit context should help the generalizability of the suggestions provided.

\section{Annex I Preliminary stakeholder analysis model}

\begin{tabular}{|c|c|c|}
\hline $\begin{array}{c}\text { Entity } \\
\text { perspective }\end{array}$ & Stakeholders & Specific notes on stakeholders' relationships \\
\hline $\begin{array}{l}\text { All entities of } \\
\text { Piazza }\end{array}$ & Students & $\begin{array}{l}\text { Present and alumni } \\
\text { Objectives } \\
\text { Provide them the highest amount of scholarships } \\
\text { Best training offer in order to find a high valuable work position } \\
\text { Theoretical training and Practical application } \\
\text { Be part of a family, self-esteem, positive future } \\
\text { Allocate the highest percentage of students in stage and find them a job } \\
\text { or perspective career } \\
\text { Best practical training offer } \\
\text { Possibility to work with awarded professional trainers (enriched their } \\
\text { CVs)Be part of a family } \\
\text { Understand the beauty in the word } \\
\text { Interactions Daily and constant; when discontinuous is due to external } \\
\text { negative influence } \\
\text { Information sharing Bi-directional, practical and theoretical, creative } \\
\text { Value High level of trust and profound involvement, "take care of" } \\
\text { Learn Mutual for definition }\end{array}$ \\
\hline Foundation & $\begin{array}{l}\text { Founders } \\
\text { Institutional founders } \\
\text { (Region) }\end{array}$ & $\begin{array}{l}\text { Historical } \\
\text { Objectives Increase the offer of services in order to meet new societal } \\
\text { need } \\
\text { Business continuity and growth } \\
\text { Increase the impact of Piazza in solving societal needs } \\
\text { Be a tool for recognize new societal needs and help public regulators as } \\
\text { new civil economy model } \\
\text { Provide the highest amount of scholarships } \\
\text { Interactions constant during the year with peaks during project } \\
\text { applications and reviews } \\
\text { Information sharing Accounting over projects; Represent an antenna on } \\
\text { the district needs; Mutual sharing of daily practices to replicate the } \\
\text { model } \\
\text { Value High level of trust } \\
\text { Learn Elevate propensity to reciprocal learn aimed to reach future } \\
\text { improvements }\end{array}$ \\
\hline
\end{tabular}




\begin{tabular}{|c|c|c|}
\hline $\begin{array}{c}\text { Entity } \\
\text { perspective }\end{array}$ & Stakeholders & Specific notes on stakeholders' relationships \\
\hline & $\begin{array}{l}\text { Donors and } \\
\text { Institutional donors } \\
\text { Partners (Private } \\
\text { Companies) } \\
\text { Small donors }\end{array}$ & $\begin{array}{l}\text { Historical, Prospective, One-shot } \\
\text { Objectives Transparency and accountability } \\
\text { Best practice for the district } \\
\text { Efficient allocation of funds } \\
\text { Visibility } \\
\text { Be involved in training programme in order to contribute to the training } \\
\text { of their perspective employees } \\
\text { Provide the highest amount of scholarships to students } \\
\text { Partner in CSR actions } \\
\text { Interactions Depending on projects (constant or discontinuous); } \\
\text { tendency to getting more involved in projects. } \\
\text { Information sharing Accounting over projects; usually mono- } \\
\text { directional, but bi-directional when partners are active part in teaching } \\
\text { and lectures } \\
\text { Value High level of trust and continuity; transparency; accuracy. } \\
\text { Learn Mutual in order to build long term relationships }\end{array}$ \\
\hline & $\begin{array}{l}\text { Human resources } \\
\text { (managerial and } \\
\text { technical staff) }\end{array}$ & $\begin{array}{l}\text { Historical, Prospective } \\
\text { Objectives } \\
\text { Internal welfare } \\
\text { Be part of a family of Piazza } \\
\text { Recognition } \\
\text { Interactions Daily } \\
\text { Information sharing Continuous share } \\
\text { Value High level of trust to assure the continuity and the guarantee the } \\
\text { imagine of Piazza as "safe place" } \\
\text { Learn New training needs that require new supports }\end{array}$ \\
\hline & $\begin{array}{l}\text { Association and other } \\
\text { firms }\end{array}$ & $\begin{array}{l}\text { Historical, Prospective } \\
\text { Objectives Build up new business networks to collaborate and offer new } \\
\text { professional training skills } \\
\text { Efficient cost allocation } \\
\text { Business partnering } \\
\text { Interactions Discontinuous } \\
\text { Information sharing Open and effective in order to increase mutual } \\
\text { benefit } \\
\text { Value Cooperation and collaboration, excluding competition }\end{array}$ \\
\hline \multirow[t]{2}{*}{$\begin{array}{l}\text { Training } \\
\text { agencies and } \\
\text { job centers }\end{array}$} & Family & $\begin{array}{l}\text { Historical, Prospective } \\
\text { Objectives Positive future and "taking care of" } \\
\text { Definitive exit from critical situation of social disease } \\
\text { Best training offer in order to find a high valuable work position } \\
\text { Interactions Constant involvement and engagement, "forced in } \\
\text { particular case" } \\
\text { Information sharing "Training deal signed by three Piazza, the students } \\
\text { and the family". Sometimes not always easy, critical and urgent. } \\
\text { Value High level of trust for the future of the family itself }\end{array}$ \\
\hline & $\begin{array}{l}\text { Social services } \\
\text { (sometimes instead of } \\
\text { families) } \\
\text { Armed forces } \\
\text { Local social educators }\end{array}$ & $\begin{array}{l}\text { Historical, important for the future } \\
\text { Objectives Prevent critical situation at high social risk } \\
\text { Prevent and tackle the risk of violence and domestic abuses } \\
\text { Prevent new social problems } \\
\text { Interactions In specific cases } \\
\text { Information sharing Critical and sensitive } \\
\text { Value High level of trust and rapidity } \\
\text { Learn Reciprocal and mutual learn in order to tackle and prevent high } \\
\text { risky situation in time }\end{array}$ \\
\hline
\end{tabular}




\begin{tabular}{|c|c|c|}
\hline $\begin{array}{c}\text { Entity } \\
\text { perspective }\end{array}$ & Stakeholders & Specific notes on stakeholders' relationships \\
\hline & $\begin{array}{l}\text { Local entities (cities, } \\
\text { province...) } \\
\text { Ministries }\end{array}$ & $\begin{array}{l}\text { Historical } \\
\text { Objectives Active role of Piazza in the district and community } \\
\text { Public outcomes } \\
\text { Effective results of the project financed by them } \\
\text { Piazza as local best practice } \\
\text { Interactions Constant and increasingly accentuated over time depending } \\
\text { on reciprocal benefit } \\
\text { Information sharing Normative, usually mono-directional, but Piazza } \\
\text { aims to foster bi-directional dialogues } \\
\text { Value Cooperation } \\
\text { Learn Influence of Piazza as national and international best practice }\end{array}$ \\
\hline & $\begin{array}{l}\text { Trainers } \\
\text { Teachers }\end{array}$ & $\begin{array}{l}\text { Historical and perspective } \\
\text { Objectives Be part of a family of Piazza } \\
\text { Well-designed training activities } \\
\text { Be more than a teacher } \\
\text { Be creative and patient } \\
\text { Interactions Daily on routine basis } \\
\text { Information sharing From trainers to students and also from trainers to } \\
\text { Piazza as a whole } \\
\text { Value Collaboration, trust, role of guide }\end{array}$ \\
\hline & $\begin{array}{l}\text { Association and other } \\
\text { partners }\end{array}$ & $\begin{array}{l}\text { Historical and perspective } \\
\text { Objectives Innovative training methodology } \\
\text { Qualified workforce } \\
\text { Partnering for projects and programme } \\
\text { Interactions Depending on projects }\end{array}$ \\
\hline & Customers & Objectives Effective job centers \\
\hline \multirow[t]{3}{*}{ Cooperative } & Customers & $\begin{array}{l}\text { Objectives } \\
\text { High level quality and premium price } \\
\text { Excellent taste } \\
\text { Functional locations }\end{array}$ \\
\hline & Professional trainers & $\begin{array}{l}\text { Historical and perspective } \\
\text { Objectives } \\
\text { Professional proud } \\
\text { Exclusivity } \\
\text { Visibility } \\
\text { Be the sounding board to attract students and customers } \\
\text { Interactions Daily on routine basis } \\
\text { Information sharing From trainers to students and from trainers to } \\
\text { Piazza as a whole. } \\
\text { Value Collaboration, reciprocal trust, role of guide }\end{array}$ \\
\hline & Suppliers & $\begin{array}{l}\text { Interactions Distinguishing between core suppliers and others } \\
\text { Objectives } \\
\text { Highest level of quality and excellence of the raw materials } \\
\text { Reciprocal trust }\end{array}$ \\
\hline \multirow[t]{2}{*}{ Association } & $\begin{array}{l}\text { Students } \\
\text { Student as members }\end{array}$ & $\begin{array}{l}\text { Historical and perspective and alumni } \\
\text { Invest their time in valuable activities to prevent social risks } \\
\text { Help other students }\end{array}$ \\
\hline & Volunteers & $\begin{array}{l}\text { Objectives } \\
\text { Give a practical help (for instance during training sessions) } \\
\text { Guarantee a professional help }\end{array}$ \\
\hline
\end{tabular}

\section{References}

\section{$\mathrm{AQ}_{4}$}


Argandoña, Antonio, and Heidi von Weltzien Høivik. 2009. Corporate social responsibility: One size does not fit all. Collecting evidence from Europe. Journal of Business Ethics 89: 221-234.

Barringer, Bruce R., and Jeffrey S. Harrison. 2000. Walking a tightrope: Creating value through interorganizational relationships. Journal of Management 26: 367-403.

Battaglia, Massimo, Lara Bianchi, Marco Frey, and Emilio Passetti. 2015. Sustainability reporting and corporate identity: action research evidence in an Italian retailing cooperative. Business Ethics: A European Review 24: 52-72. doi: 10.1111/beer.12067.

Bhattacherjee, Anol. 2012. Social science research: principles, methods, and practices. Tampa: University of South Florida.

Boesso, Giacomo, and Kamalesh Kumar. 2009. Stakeholder prioritization and reporting: Evidence from Italy and the US. Accounting Forum 33: 162-175. doi: 10.1016/j.accfor.2008.07.010 .

Brown, L. David. 1985. People-centered development and participatory research. Harvard Educational Review 55 (1): 69-76.

Buchholz, Rogene A., and Sandra B. Rosenthal. 2005. Toward a contemporary conceptual framework for stakeholder theory. Journal of Business Ethics 58: 137-148. doi: 10.1007/s10551-005-1393-8 .

Clarkson, Max E. 1995. A Stakeholder Framework for Analyzing and Evaluating Corporate Social Performance. Academy of Management Review 20: 92-117. doi: 10.5465/AMR.1995.9503271994 .

Coghlan, David, and Teresa Brannick. 2014. Doing action research in your own organization. London: Sage.

Corazza, Laura, and Maurizio Cisi. 2012. Accountability challenges in social enterprise and the implementation of a reporting standard: An Italian case study. Journal of Social Business 2: 44-67.

Costa, Ericka, and Tommaso Ramus. 2012. The Italian economia aziendale and catholic social teaching: How to apply the common food principle at the managerial level. Journal of Business Ethics 106: 103-116. doi: 10.1007/s10551-011-1056-X .

Cots, Elisabet Garriga. 2011. Stakeholder social capital: A new approach to stakeholder theory. Business Ethics: A European Review 20: 328-341. doi: 10.1111/j.1467-8608.2011.01635.x .

Crane, Andrew, and Trish Ruebottom. 2011. Stakeholder theory and social identity: rethinking stakeholder identification. Journal of Business Ethics 102: 77-87. doi: 10.1007/s10551-011-1191-4 .

Darwin, John. 1999. Action Research: Theory, Practice and Trade Union Involvement. Working paper no. 99/06. Sheffield, Sheffield Business School.

Dickens, Linda, and Karen Watkins. 1999. Action research: rethinking Lewin. Management Learning 30: $127-140$.

Donaldson, Thomas, and Lee E. Preston. 1995. The stakeholder theory of the corporation: Concepts, evidence and implications. Academy of Management Review 20: 65-91. doi:

10.5465/AMR.1995.9503271992 .

Eden, Colin, and Chris Huxman. 1996. Action research for the study of organisations. In Handbook of Organisational Studies, ed. Steward R. Clegg, Cynthia Hardy, and Walter R. Nord, 526-542. Washington: Sage.

Elliot, John. 1991. Action research for educational change. McGraw-Hill Education (UK). 
Evan, William, and R. Edward Freeman. 1993. A stakeholder theory of the modern corporation: Kantian capitalism. In Ethical Theory and Business, ed. Tom Beauchamp and Norman Bowie, 75-84. Englewood Cliffs: Prentice Hall.

Ferrero, Giovanni. 1987. Impresa e management. Milano: Giuffrè.

Freeman, R. Edward. 1984. Strategic Management: A Stakeholder Approach. Boston: Pitman.

1994. The politics of stakeholder theory: Some future directions. Business Ethics Quarterly 4: 409421. doi: $10.2307 / 3857340$.

Freeman, R. Edward, Jeffrey S. Harrison, and Andrew C. Wicks. 2007a. Managing for stakeholders. Survival, reputation, and success. London: Yale University Press.

Freeman, R. Edward, Jeffrey S. Harrison, Andrew C. Wicks, Bidhan Parmar, and Simone De Colle. 2010. Stakeholder theory: The state of the art. Cambridge: Cambridge University Press.

Freeman, R. Edward, Martin Kirsten, and Bidhan Parmar. 2007b. Stakeholder capitalism. Journal of Business Ethics 74: 303-314. doi: 10.1007/s10551-007-9517-y .

Freeman, R. Edward, and John McVea. 2001. A Stakeholder Approach to Strategic Management. Darden Business School Working Paper. No. 01-02. doi: 10.2139/ssrn.263511

Freeman, R. Edward, and Alexander Moutchnik. 2013. Stakeholder management and CSR: questions and answers. uwfUmweltWirtschaftsForum 21:5-9. doi: 10.1007/s00550-013-0266-3

Freeman, R. Edward, and Robert Phillips. 2002. Stakeholder Theory: A Libertarian Defence. Business Ethics Quarterly 12: 331-349. doi: 10.2307/3858020 .

Freeman, R. Edward, Velamuri S. Ramakrishna, and Brian Moriarty. 2006. Company stakeholder responsibility: A new approach to CSR. Business Roundtable Institute for Corporate Ethics.

Freeman, R. Edward, and David L. Reed. 1983. Stockholders and Stakeholders: A New Perspective on Corporate Governance. California Management Review 25: 88-106. doi: 10.2307/41165018 .

Freeman, R. Edward, Gianfranco Rusconi, Silvana Signori, and Alan Strudler. 2012. Stakeholder theory(ies): Ethical ideas and managerial action. Journal of Business Ethics 109: 1-2. doi: 10.1007/s10551-012-1374-7 .

Freeman, R. Edward, Andrew C. Wicks, and Bidhan Parmar. 2004. Stakeholder theory and "The corporate objective revisited”. Organization Science 15: 364-369. doi: 10.1287/orsc.1040.0066.

Goodpaster, Kenneth. 1991. Business Ethics and Stakeholder Analysis. Business Ethics Quarterly 1: 53-73. doi: $10.2307 / 3857592$.

Greenwood, J. Davydd, and Morten Levin. 2007. Introduction to action research, social research for social change. 2nd ed. Thousand Oaks: Sage.

Harland, Christine M., Richard C. Lamming, Jurong Zheng, and Thomas E. Johnsen. 2001. A Taxonomy of Supply Networks. Journal of Supply Chain Management 3: 21-27. doi: 10.1111/j.1745-

493X.2001.tb00109.x .

Jackson, O. Matthew. 2010. Social and Economic Networks. Princeton: Princeton University Press.

Kemmis, Stephen, and Robin McTaggart. 2000. Participatory Action Research. In Handbook of Qualitative Research, ed. Norman K. Denzin and Yvonna S. Lincoln, 2nd ed., 567-605. Thousand Oaks, CA: Sage 
Publications.

Koshy, Elizabeth, Valsa Koshy, and Heather Waterman. 2010. Action research in healthcare. London: Sage.

Kujala, Johanna, Anna Heikkinen, and Hanna Lehtimäki. 2012. Understanding the nature of stakeholder relationships: An empirical examination of a conflict situation. Journal of Business Ethics 109: 53-65. doi: 10.1007/s10551-012-1379-2 .

Lozano, Josep M. 2005. Towards the relational corporation: From managing stakeholder relationship to building stakeholder relationships (waiting for Copernicus). Corporate Governance 5: 60-77. doi: $10.1108 / 14720700510562668$.

McVea, John F., and R. Edward Freeman. 2005. A names-and-faces approach to stakeholder management: How focusing on stakeholders as individuals can bring ethics and entrepreneurial strategy together. Journal of Management Inquiry 14: 57-69. doi: 10.1177/1056492604270799 .

Minoja, Mario. 2012. Stakeholder management theory, firm strategy, and ambidexterity. Journal of Business Ethics 109: 67-82. doi: 10.1007/s10551-012-1380-9 .

Minoja, Mario, Maurizio Zollo, and Vittorio Coda. 2010. Stakeholder cohesion, innovation, and competitive advantage. Corporate Governance: An International Journal of Business in Society 10: 395-405. doi: $10.1108 / 14720701011069632$.

Mitchell, Ronald K., Bradley R. Agle, and Donna J. Wood. 1997. Toward a theory of stakeholder identification and salience: Defining the principle of who and what really counts. The Academy of Management Review 22: 853-886. doi: 10.5465/AMR.1997.9711022 .

Myllykangas, Päivi, Johanna Kujala, and Hanna Lehtimäki. 2010. Analyzing the essence of stakeholder relationships: What do we need in addition to power, legitimacy, and urgency? Journal of Business Ethics 96: 65-72. doi: 10.1007/s10551-011-0945-3 .

O'Leary, Zina. 2004. The essential guide to doing research. London: Sage.

Pfeffer, Jeffrey. 1981. Power in organizations. Marshfield: Pitman.

Phillips, Robert. 2003. Stakeholder legitimacy. Business Ethics Quarterly 13: 25-41. doi: $10.5840 /$ beq20031312.

Phillips, Robert, R. Edward Freeman, and Andrew C. Wicks. 2003. What stakeholder theory is not. Business Ethics Quarterly 13: 479-502. doi: 10.5840/beq200313434 .

Post, James E., Lee E. Preston, and Sybille Sachs. 2002. Managing the extended enterprise: the new stakeholder view. California Management Review 45: 6-28. doi: 10.2307/41166151 .

Ragazzi, Elena. 2008. Perchè nessuno si perda: la Piazza dei mestieri: un modello per contrastare la dispersione scolastica. Milano: Guerini e associati.

Reason, Peter, and Hilary Bradbury, eds. 2001. Handbook of action research: Participative inquiry and practice. London: Sage.

Rosenfeld, A. Stuart. 1995. Industrial-Strength Strategies: Regional Business Clusters and Public Policy. Washington, DC: Aspen Institute.

Rowley, Timothy J. 1997. Moving beyond dyadic ties: A network theory of stakeholder influences. Academy of Management Review 22: 887-910. doi: 10.5465/AMR.1997.9711022107 . 
Signori, Silvana, and Gianfranco Rusconi. 2009. Ethical thinking in traditional Italian economia aziendale and the stakeholder management theory: The search for possible interactions. Journal of Business Ethics 89: 303-318. doi: 10.1007/s10551-010-0391-7 .

Suchman, Mark C. 1995. Managing legitimacy: Strategic and institutional approaches. Academy of Management Review 20: 571-610. doi: 10.5465/AMR.1995.9508080331 .

Susman, Gerald I., and Roger D. Evered. 1978. An assessment of the scientific merits of action research. Administrative Science Quarterly: 582-603. doi: 10.2307/2392581 .

Tencati, Antonio, and Laszlo Zsolnai. 2009. The collaborative enterprise. Journal of Business Ethics 85: 367-376. doi: 10.1007/s10551-008-9775-3 .

Whyte, William Foote. 1989. Advancing scientific knowledge through participatory action research. Sociological Forum 4: 367-385. doi: 10.1007/BF01115015.

Whyte, William Foote, Davydd J. Greenwood, and Peter Lazes. 1989. Participatory action research. The American Behavioral Scientist 32: 513.

Wicks, Andrew, and R. Edward Freeman. 1998. Organization studies and the new pragmatism: Positivism, antipositivism and the search for ethics. Organization Science 9: 123-140. doi: 10.1287/orsc.9.2.123 .

Zappa, Gino. 1962. L'economia delle aziende di consumo. Milano: Dott. A. Giuffrè Editore. 